\title{
Curcumin induces apoptosis through FAS and FADD, in caspase-3-dependent and -independent pathways in the N18 mouse-rat hybrid retina ganglion cells
}

\author{
HSU-FENG LU ${ }^{1}$, KUANG-CHI LAI ${ }^{2,5}$, SHU-CHUN HSU ${ }^{6}$, HUI-JU LIN ${ }^{3}$, \\ MEI-DUE YANG ${ }^{4}$, YUAN-LIANG CHEN ${ }^{9}$, MING-JEN FAN ${ }^{10}$, JAI-SING YANG ${ }^{7}$, \\ PI-YUN CHENG ${ }^{11}$, CHAO-LIN KUO ${ }^{6}$ and JING-GUNG CHUNG ${ }^{8,10}$
}

\begin{abstract}
${ }^{1}$ Department of Clinical Pathology, Cheng Hsin Rehabilitation Medical Center, Taipei 112; Departments of ${ }^{2}$ Medicine,
${ }^{3}$ Ophthalmology and ${ }^{4}$ Surgery, China Medical University Hospital, Taichung $404 ;{ }^{5}$ Department of Surgery,

China Medical University Beigang Hospital, Yunlin 651; ${ }^{6}$ Institute of Chinese Pharmaceutical Sciences,

Departments of ${ }^{7}$ Pharmacology and ${ }^{8}$ Biological Science and Technology, China Medical University,

Taichung 404; ${ }^{9}$ Depatment of Medical Technology, Yuan-Pei Institute of Science and Technology,

Hsinchu 300; ${ }^{10}$ Department of Biotechnology, Asia University, Wufeng, Taichung 413;

${ }^{11}$ Department of Chemistry, National Changhua University of Education, Changhua 500, Taiwan, R.O.C.
\end{abstract}

Received January 14, 2009; Accepted March 26, 2009

DOI: 10.3892/or_00000411

\begin{abstract}
Curcumin, a naturally occurring yellow pigment isolated from turmeric, is a well known antioxidant with broad spectrum of anti-tumor activities against many human cancer cells. In this study, curcumin-induced cytotoxic effect of mouse-rat hybrid retina ganglion cells (N18) were investigated. For determining cell viability, the trypan blue exclusion and flow cytometric analysis were used. The curcumin-caused cell cycle arrest in N18 cells was examined by flow cytometry. Curcumin affect on the production of reactive oxygen species and $\mathrm{Ca}^{2+}$ and on the decrease of the level of mitochondria membrane potential $\left(\Delta \Psi_{\mathrm{m}}\right)$ were also examined by flow cytometry. Curcumin-induced apoptosis was determined by DAPI staining and Western blotting was used for examining the apoptotic signaling proteins. Cell cycle analysis showed that $\mathrm{G} 2 / \mathrm{M}$ phase arrest and sub-G1 occurs in N18 cells following $48 \mathrm{~h}$ exposure to curcumin. Curcumin also caused a marked increase in apoptosis, as characterized by DNA fragmentation (sub-G1 phase formation) and DAPI staining, and dysfunction of mitochondria, which was associated with the activation of caspase- $8,-9$ and -3 . Curcumin also promoted the levels of Fas and FADD, Bax, cytochrome c release, but decreased the levels of Bcl-2 causing changes of $\Delta \Psi_{\mathrm{m}}$. Curcumin also induced endoplasmic reticulum stress in N18 cells which was
\end{abstract}

Correspondence to: Dr J.-G. Chung, Department of Biological Science and Technology, China Medical University, No. 91, Hsueh-Shih Road, Taichung City 404, Taiwan, R.O.C.

E-mail: jgchung@mail.cmu.edu.tw

Key words: curcumin, cell cycle arrest, apoptosis, caspase, mitochondria, mouse-rat hybrid retina ganglion N18 cells based on the changes of GADD153 and GRP78 and caused $\mathrm{Ca}^{2+}$ release. Curcumin induced apoptosis through the intrinsic pathway and caspase-3-dependent and -independent pathways in $\mathrm{N} 18$ cells.

\section{Introduction}

Apoptosis is a highly regulated mechanism in which the cells undergo programmed cell death (1) and the two main apoptosis pathways are the extrinsic and the intrinsic pathway (2). The extrinsic pathway is initiated through the interaction of ligands and surface receptors (3) including CD95/Fas/Apo1, tumor necrosis factor receptor 1 (TNFR1), TNF receptor 2 (TNFR2) and death receptors 3-6 (DR3-6) (1), and they deliver a death signal from the extracellular microenvironment to the cytoplasm before leading to apoptosis. The intrinsic pathway is initiated through stimuli such as DNA damage, hypoxia, cell detachment, cellular distress and cytotoxic drugs, which act inside the cell (1). Proteins associated with apoptosis can be divided into the pro-apoptotic such as Bax and Bad antiapoptotic such as Bcl-2 and Bcl-xl $(4,5)$ and if one of the pro-apoptotic and anti-apoptotic proteins is overexpressed, it will lead to the dysfunction of mitochondria of pro- and anti-apoptotic proteins leading to cytochrome c release and causing the activation of caspase- 3 that leads to apoptosis (6).

Curcumin (diferuloylmethane) is an antioxidant and antiinflammatory substance (7). It was reported that the dietary treatment of $0.5-2 \%$ curcumin in mice inhibited the incidence and size of colonic, small intestinal and gastric cancers induced by azoxymethane $(8,9)$. Curcumin inhibited proliferation and caused cell cycle arrest in colon adenocarcinoma cell lines by a prostaglandin-independent pathway (10). Curcumin inhibited the expression of oncogenes c-jun, c-fos, and c-myc in animals and cell lines $(11,12)$ and the 
activity of the AP-1 transcription factor in cells stimulated to proliferate (13). Curcumin was found to be cytotoxic in rat hepatocytes (14) and to stimulate oxidative damage caused by quertecin in rat hepatocytes (15). Investigators also pointed out that curcumin inhibited proteasomal activity (16), caused the accumulation of cytosolic $\mathrm{Ca}^{2+}(17,18)$ and disrupt protein disulfide bond formation (19). Curcumin also induced apoptosis in some cells and may be associated with endoplasmic reticulum stress $(19,20)$. However, there is no available information to address the effects of curcumin on mouse-rat hybrid retina ganglion N18 cells. Therefore, in this study, we investigated the induction of cell cycle arrest and apoptosis and the role of reactive oxygen species in mouserat hybrid retina ganglion N18 cells and also show the possible signaling pathways.

\section{Materials and methods}

Cell culture. Mouse-Rat Hybrid retina ganglion cell line (N18: derived from retina ganglion cells hybrid with lymphoma cells) was purchased from Japanese Collection of Research Bioresources Bank. Cells are cultured in DMEM medium supplemented with $10 \%$ FBS, $1 \%$ penicillin-streptomycin (100 U/ml penicillin and $100 \mathrm{ng} / \mathrm{ml}$ streptomycin) and $1 \%$ L-glutamine. All cells were cultured in a humidified atmosphere of $5 \% \mathrm{CO}_{2}$ and $95 \%$ air at $37^{\circ} \mathrm{C}$. Cells were cultured for several generations, and have been checked for viability as described previously (21).

Trypan blue exclusion assay. N18 cells were trypsinized, isolated and collected by centrifugation. An aliquot of collected cells was mixed with trypan blue dye (Sigma) to final concentration of $0.04 \% \mathrm{w} / \mathrm{v}$ ), loaded onto a hemocytometer, and counted under a microscope $(21,22)$.

Viability determination. Cells were analyzed for percentage of viable cells by flow cytometer. Cells at a density of $2 \times 10^{5}$ cells/well were plated onto 12 -well plates and incubated at $37^{\circ} \mathrm{C}$ for $24 \mathrm{~h}$. Different concentrations of curcumin $(0,10$, $30,50,75$ and $100 \mu \mathrm{M}$ ) were added and cells incubated for 24, 48 and $72 \mathrm{~h}$, and the floated cells were collected and adherent cells were washed once with PBS, trypsinized, and collected by centrifugation at $1000 \mathrm{x}$ g for $5 \mathrm{~min}$. The cells ( $1 \times 10^{5}$ cells per sample) were centrifuged at $1000 \mathrm{x} \mathrm{g}$ for $5 \mathrm{~min}$, cell pellets were dissolved with $0.5 \mathrm{ml}$ of PBS containing $100 \mu \mathrm{g} / \mathrm{ml}$ RNase and $5 \mu \mathrm{g} / \mathrm{ml}$ propidium iodide and viable cells were determined by using a flow cytometer (Beckman Coulter, Inc., Fullerton, CA, USA) $(21,22)$.

Cell cycle analysis by flow cytometry. Cells were analyzed for their cell cycle and sub-G1 (apoptosis) distribution by flow cytometer. Cells at a density of $2 \times 10^{5}$ cells/well were plated onto 12 -well plates and incubated at $37^{\circ} \mathrm{C}$ for $24 \mathrm{~h}$. Different concentrations of curcumin $(0,5,10,20,30$ and $50 \mu \mathrm{M}$ ) were added and cells incubated for $48 \mathrm{~h}$, while the adherent cells were washed once with PBS, trypsinized, and collected by centrifugation at $1000 \mathrm{x}$ g for $5 \mathrm{~min}$. The cells ( $1 \times 10^{5}$ cells per sample) were fixed in $2 \mathrm{ml}$ of cold $70 \%$ ethanol at $-20^{\circ} \mathrm{C}$ overnight before cells were centrifuged at $1000 \mathrm{x} \mathrm{g}$ for $5 \mathrm{~min}$, and the cell pellets were incubated with

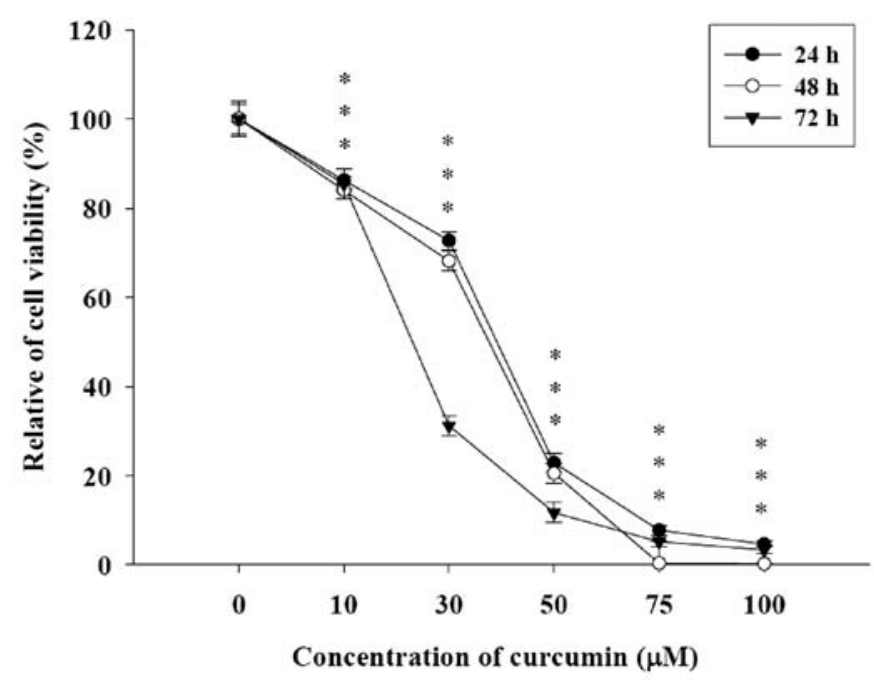

Figure 1. Curcumin effects on cell viability in N18 cells. Cells were cultured with various concentrations of curcumin for 24,48 and $72 \mathrm{~h}$ and were collected by centrifugation. Then for percentage of total viable cells, they were counted by PI-incorporation and flow cytometric analysis as described in Materials and methods. Each point is mean $\pm \mathrm{SD}$ of three experiments; ${ }^{* * *} \mathrm{P}<0.001$

$0.5 \mathrm{ml}$ of PBS containing $100 \mu \mathrm{g} / \mathrm{ml}$ RNase and $5 \mu \mathrm{g} / \mathrm{ml}$ propidium iodide at $37^{\circ} \mathrm{C}$ for $30 \mathrm{~min}$. Cell cycle and sub-G1 distributions were analyzed by measuring DNA content using a flow cytometer $(21,22)$.

Detection of reactive oxygen species, $\mathrm{Ca}^{2+}$ levels and mitochondrial membrane potential. Cells at a density of $2 \times 10^{5}$ cells/well were plated onto 12 -well plates and treated with $30 \mu \mathrm{M}$ of curcumin for $0,3,6,12,24,48$ and $72 \mathrm{~h}$. Cells were harvested, washed twice with PBS, and re-suspended in the $500 \mu 1$ of ROS indicator 2,7-dichlorodihydrofluorescein diacetate (H2DCF-DA), $500 \mu 1$ of calcium probe Indo 1/AM and $500 \mu 1$ of the mitochondrial membrane potential indicator 3, 3'-dihexyloxacarbocyanine iodide $\left(\mathrm{DiOC}_{6}\right)$ and incubated at $37^{\circ} \mathrm{C}$ for $30 \mathrm{~min}$ then to detect changes in ROS, $\mathrm{Ca}^{2+}$ levels and mitochondrial membrane potential by using flow cytometry as previously described (23).

Western blotting. Cells at a density of $2 \times 10^{6}$ cells/well were plated onto 6-well plates and incubated at $37^{\circ} \mathrm{C}$ for $24 \mathrm{~h}$. Curcumin $(30 \mu \mathrm{M})$ was added and cells incubated for 0,6 , 12,24 and $48 \mathrm{~h}$. The cells were lysed and protein concentration was determined using the BCA assay. Protein samples were separated by SDS-PAGE (12\%) and electrotransferred onto PVDF membrane. The membrane was incubated with specific primary antibodies. Mouse antihuman Bax, Bcl-2, cytochrome c, Apaf-1, AIF, GADD153, GRP78, Fas, FADD, caspase-8, -9 and -3 antibodies were from Santa Cruz Bio-technology (Santa Cruz, CA, USA) and B-actin was from Sigma Chemical Co. (St. Louis, MO, USA). Then cells were stained for secondary antibody. The protein levels were normalized by B-actin (22-23).

Statistical analysis. Student's t-test was used to analyze all experimental data, with $\mathrm{P}<0.05$ considered as the level of significance between control and experimental groups. 
(A)
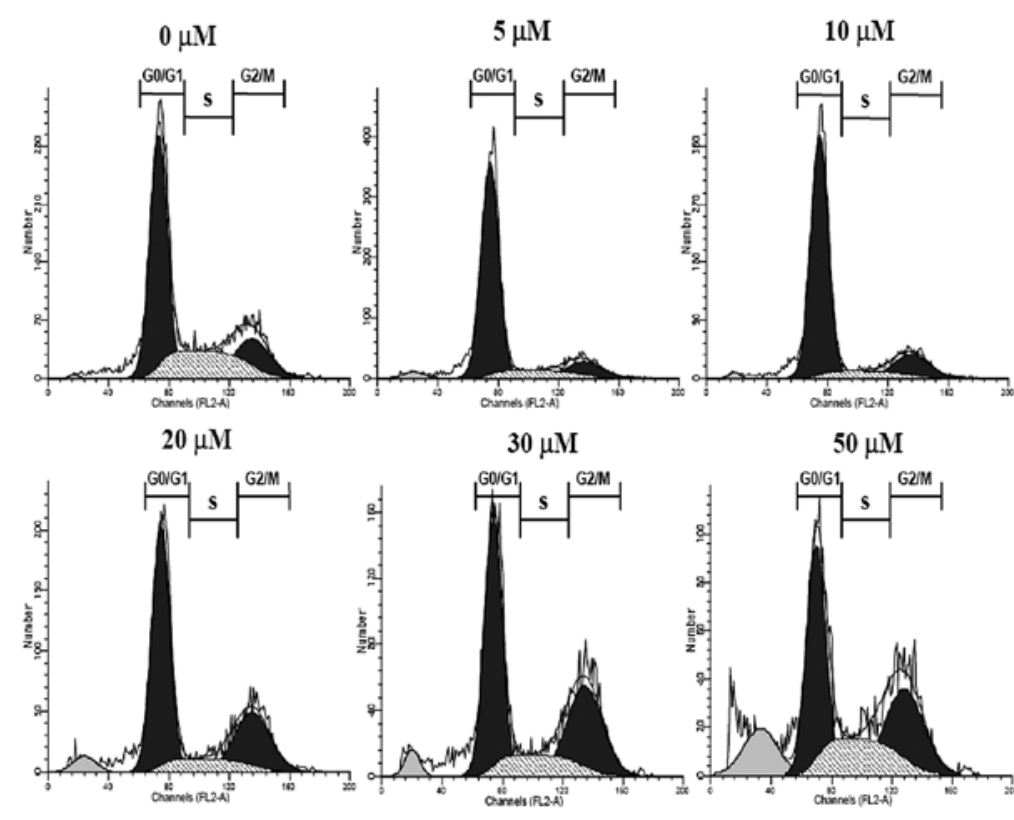

$30 \mu \mathrm{M}$

$50 \mu \mathrm{M}$

(B)
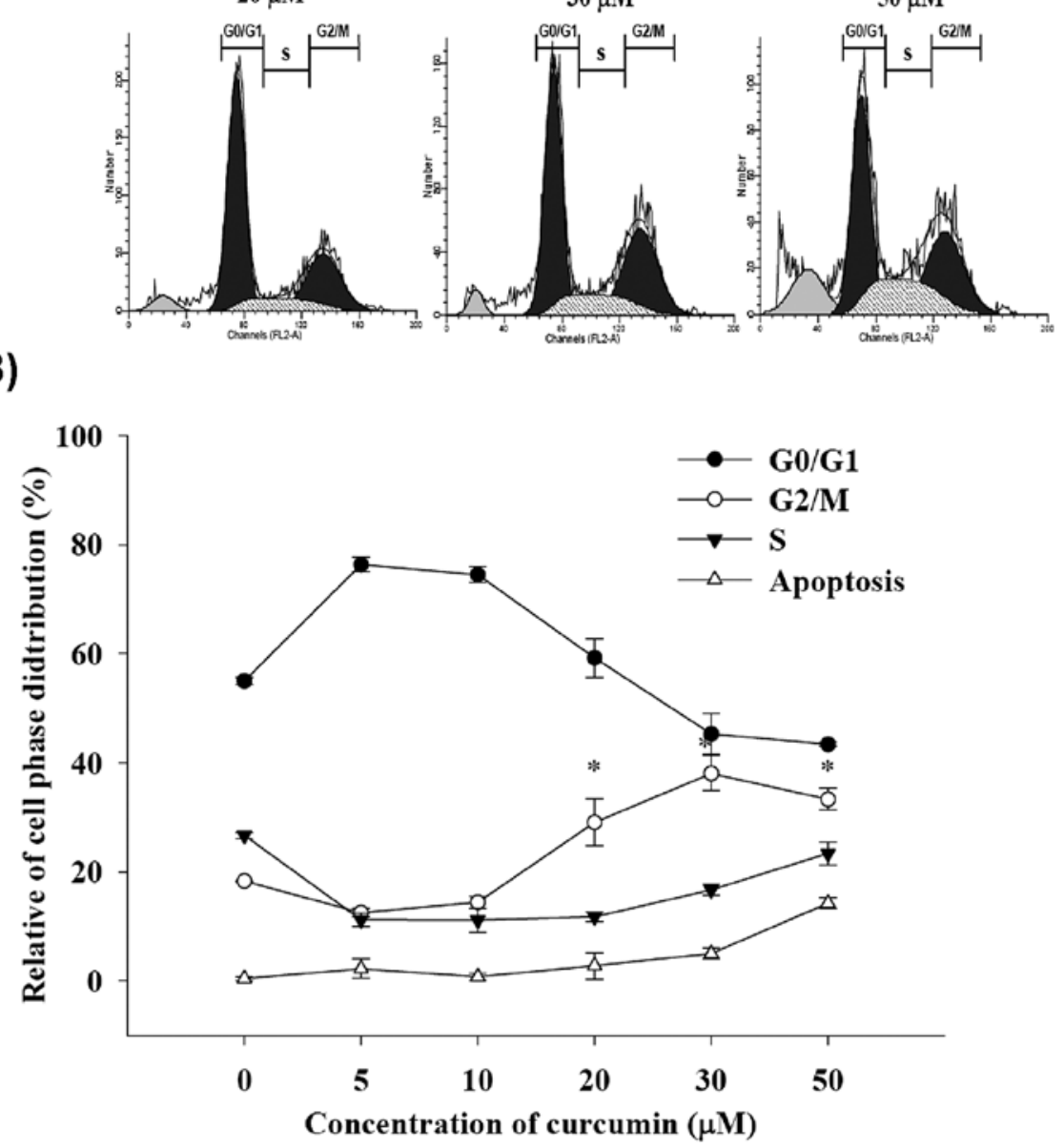

Figure 2. Curcumin effects on the cell cycle arrest and sub-G1 (apoptosis) of N18 cells, and the representative profiles (A) and percentage of each phase and apoptosis (B) on SCC-4 cells. Cells were treated with various concentrations of curcumin for $48 \mathrm{~h}$ and the cells were harvested and analyzed for cell cycle and the sub-G1 group (A) and phase distribution (B) by flow cytometry, as described in Materials and methods. Data represent mean \pm SD of three experiments; ${ }^{*} \mathrm{P}<0.05$

\section{Results}

Curcumin induces cytotoxicity in N18 mouse-rat hybrid retina ganglion cells. The effects of curcumin on N18 cells were first evaluated by trypan blue exclusion and flow cytometric assay. Both assays indicated that curcumin significantly decreased the percentages of viable N18 cells and these effects are time- and dose-dependent. As shown in Fig. 1, the viable cells at $48 \mathrm{~h}$ after the treatment with curcumin were decreased to $74.6(30 \mu \mathrm{M}), 23.4 \%(50 \mu \mathrm{M})$ and $10.2 \%(70 \mu \mathrm{M})$ of the control. We noted that at awer concentration, $10 \mu \mathrm{M}$, curcumin had little effect on the morphology of the treated cells.
Curcumin treatment alters the distribution of cell cycles and induced apoptosis. To determine whether or not curcumin exerted its cytotoxic effect via the induction of cell cycle arrest, we examined the distribution of cell cycles of N18 cells, by flow cytometry, after their exposure to curcumin. As shown in Fig. 2A and B, curcumin induced an altered cell cycle distribution in a dose-dependent manner. The percentages of cells at G0/G1 phase at $48 \mathrm{~h}$ after the treatment with curcumin were increased from low doses of curcumin (5 and $10 \mu \mathrm{M})$, the increased doses led to a decrease in the G0/G1 phase. Percentages of cells at $\mathrm{S}$ phase were slightly decreased by curcumin treatment. It should be noted that while there was no change in the percentage of cells at G2/M at lower doses 

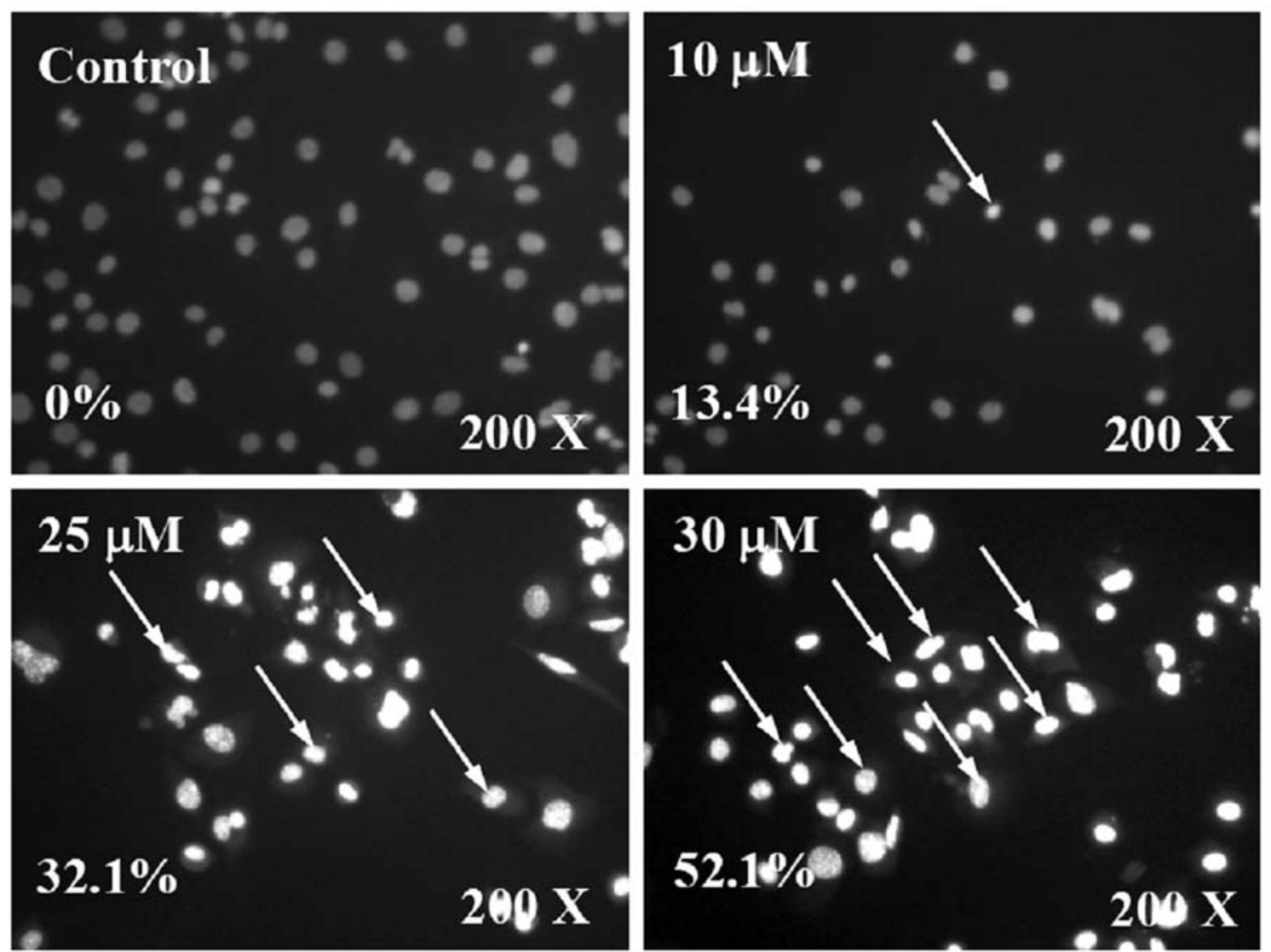

Figure 3. Curcumin-induced apoptosis in N18 cells examined by DAPI staining. N18 cells were treated with various concentrations of curcumin for $48 \mathrm{~h}$ and apoptosis was determined by DAPI staining and photographed by fluoresce microscopy (x200) as described in Materials and methods.

(5 and $10 \mu \mathrm{M}$ ), the percentage of cells at $\mathrm{G} 2 / \mathrm{M}$ was markedly increased after more than $10 \mu \mathrm{M}$ of curcumin.

The percentages of cells at $\mathrm{G} 2 / \mathrm{M}$ phase at $48 \mathrm{~h}$ after the treatment with curcumin were increased, from $20.4 \%$ in the control to $40.8 \%$. Sub-G1 was increased after 48 h treatment of curcumin to $>20 \mu \mathrm{M}$. Thus, curcumin treatment significantly reduced cells in $\mathrm{S}$ phase, leading to the accumulation of cells at $\mathrm{G} 2 / \mathrm{M}$ and increased sub-G1 phase. These results suggested that curcumin can induce cell cycle arrest at $\mathrm{G} 1$ and $\mathrm{G} 2 / \mathrm{M}$ phases and produces sub-G1 in a dose-dependent manner in N18 cells. This induction of cell cycle arrest at $\mathrm{G} 2 / \mathrm{M}$ is consistent with previous studies on other cancer cells.

Curcumin-induced apoptosis examined by DAPI staining. To determine whether cytotoxic effect of curcumin was due to apoptotic induction, morphological features such as membrane blebbing were observed in N18 cells treated with 10,25 and $30 \mu \mathrm{M}$ curcumin for $48 \mathrm{~h}$ by fluorescence microscope as shown in Fig. 3. The fluorescence microscopy indicated that DAPI staining assays revealed apoptotic cells in curcumin-treated N18 cells compared with intact control cells and this effect was dose-dependent.

Curcumin induces production of reactive oxygen species and $\mathrm{Ca}^{2+}$ and decreases the levels of mitochondria membrane potential $\left(\Delta \Psi_{m}\right)$ in N18 cells. In order to examine whether or not curcumin induced apoptosis which is associated with
ROS production, we examined the levels of ROS in N18 cells after exposure to $30 \mu \mathrm{M}$ curcumin for various time periods. The results indicated that curcumin induced ROS production quite early at $1 \mathrm{~h}$ time-dependently (Fig. 4A) up to $24 \mathrm{~h}$ of treatment, and the ROS levels were still high when compared to the control. Curcumin increased $\mathrm{Ca}^{2+}$ levels timedependently (Fig. 4B) up to $24 \mathrm{~h}$ of treatment. Mitochondrial membrane potential $\left(\Delta \Psi_{\mathrm{m}}\right)$ was reduced by curcumin in a time-dependent manner (Fig. 4C).

Curcumin affectes the levels of associated proteins in apoptosis of N18 cells. To confirm whether the cytotoxic effect of curcumin on N18 cells, as noted in flow cytometric assays, was due to apoptosis, N18 cells were cultured for $0,6,12,24$ and $48 \mathrm{~h}$ in the presence of the DMSO vehicle alone or with $30 \mu \mathrm{M}$ curcumin. Cells were harvested from each treatment and cell lysates were prepared for Western blot analysis of Bax, Bcl-2, cytochrome c, Apaf-1, AIF, GADD153, GRP78, Fas, FADD, caspase- $8,-9$ and -3 proteins expression. The results from Western blotting are shown in Fig. 5A-E. Curcumin promoted the levels of Bax (Fig. 5A), cytochrome c, Apaf-1 and AIF (Fig. 5B), GADD153 and GRP78 (Fig. 5C), Fas and FADD (Fig. 5D), but decreased Bcl-2 (Fig. 5A). However, curcumin promoted the active form of caspase- 8 , -9 and -3 (Fig. 5E). PARP-1 cleavage and a reduction in the level of pro-caspase- 3 or the production of active form of caspase-3, both as a result of caspase activity, are indicators of apoptosis $(24,25)$. As shown in Fig. 5E, a reduction in 
(A)

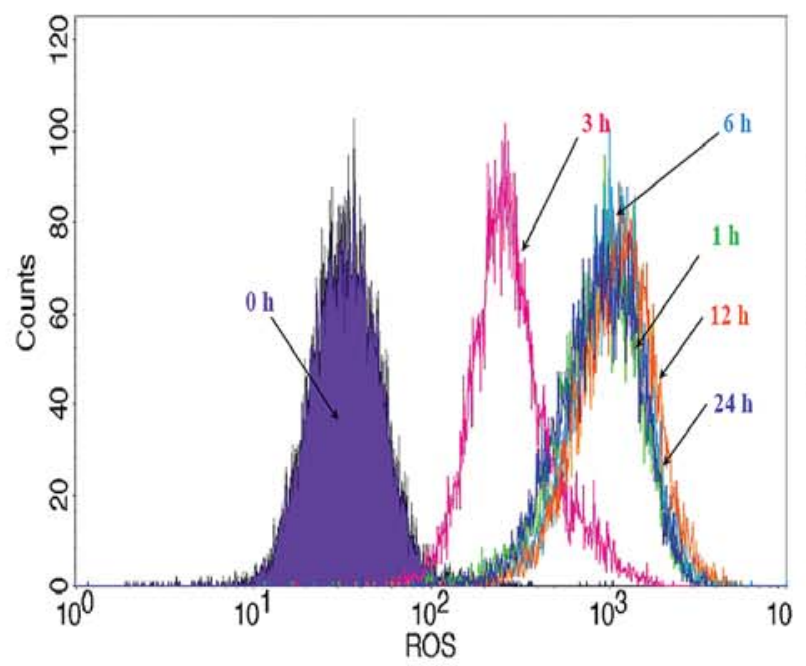

(B)

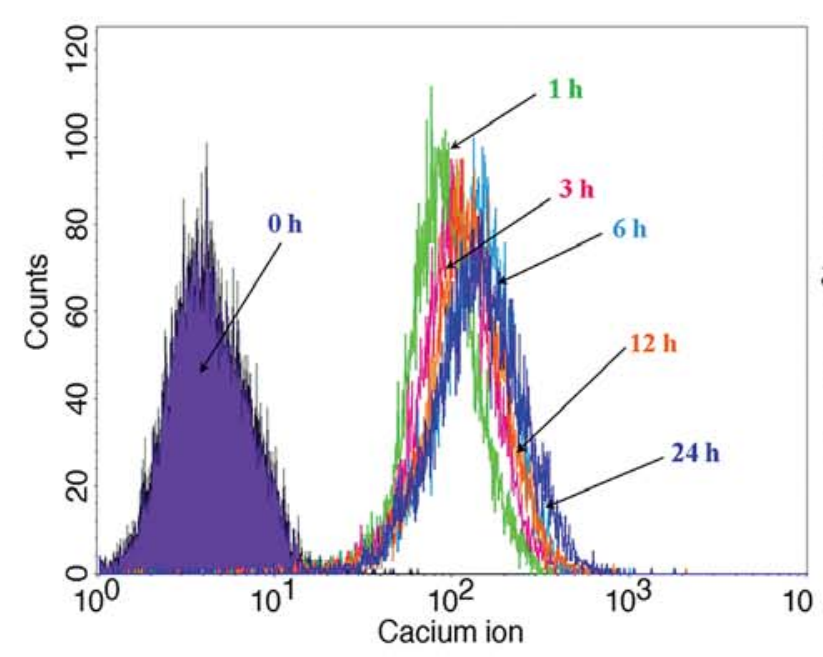

(C)

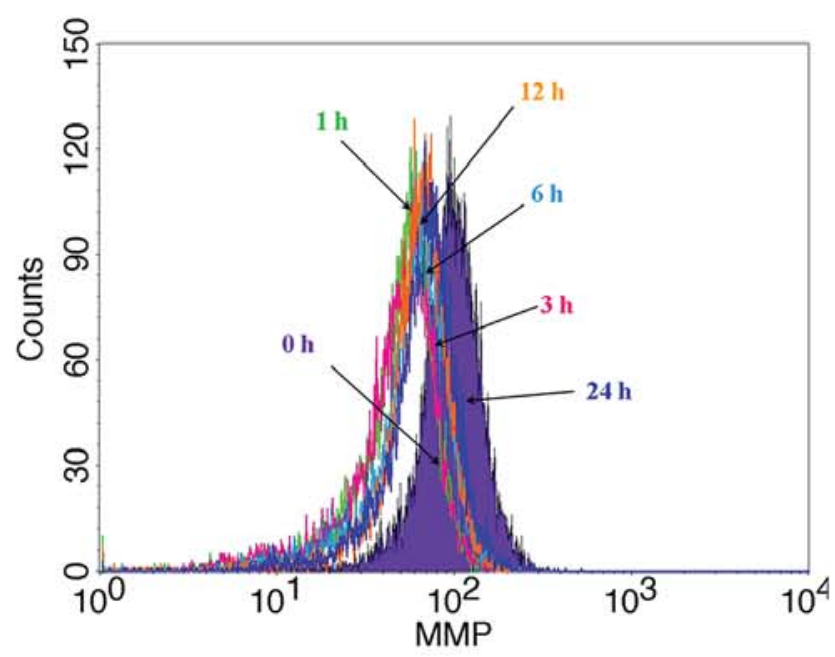

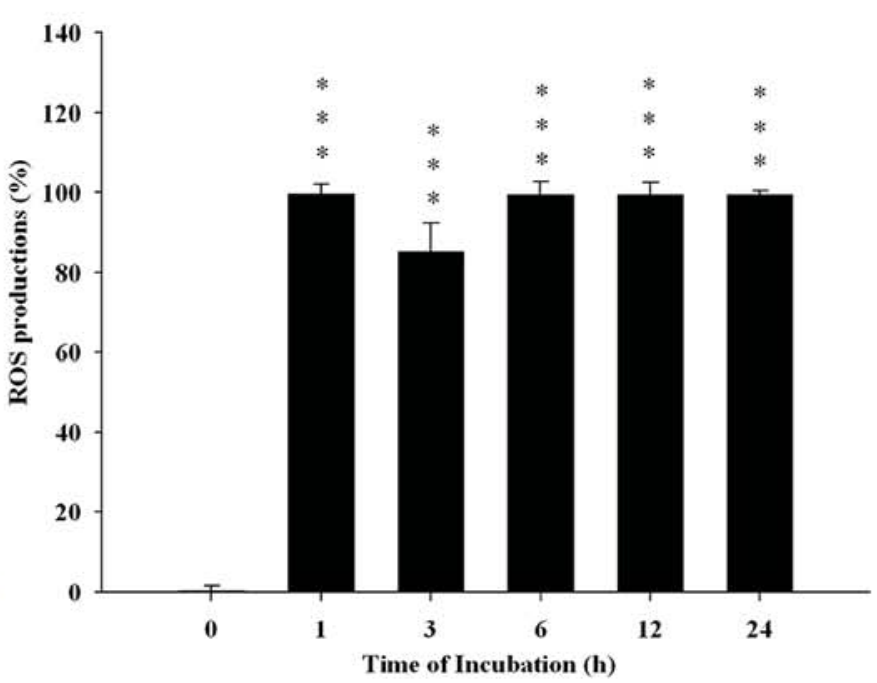
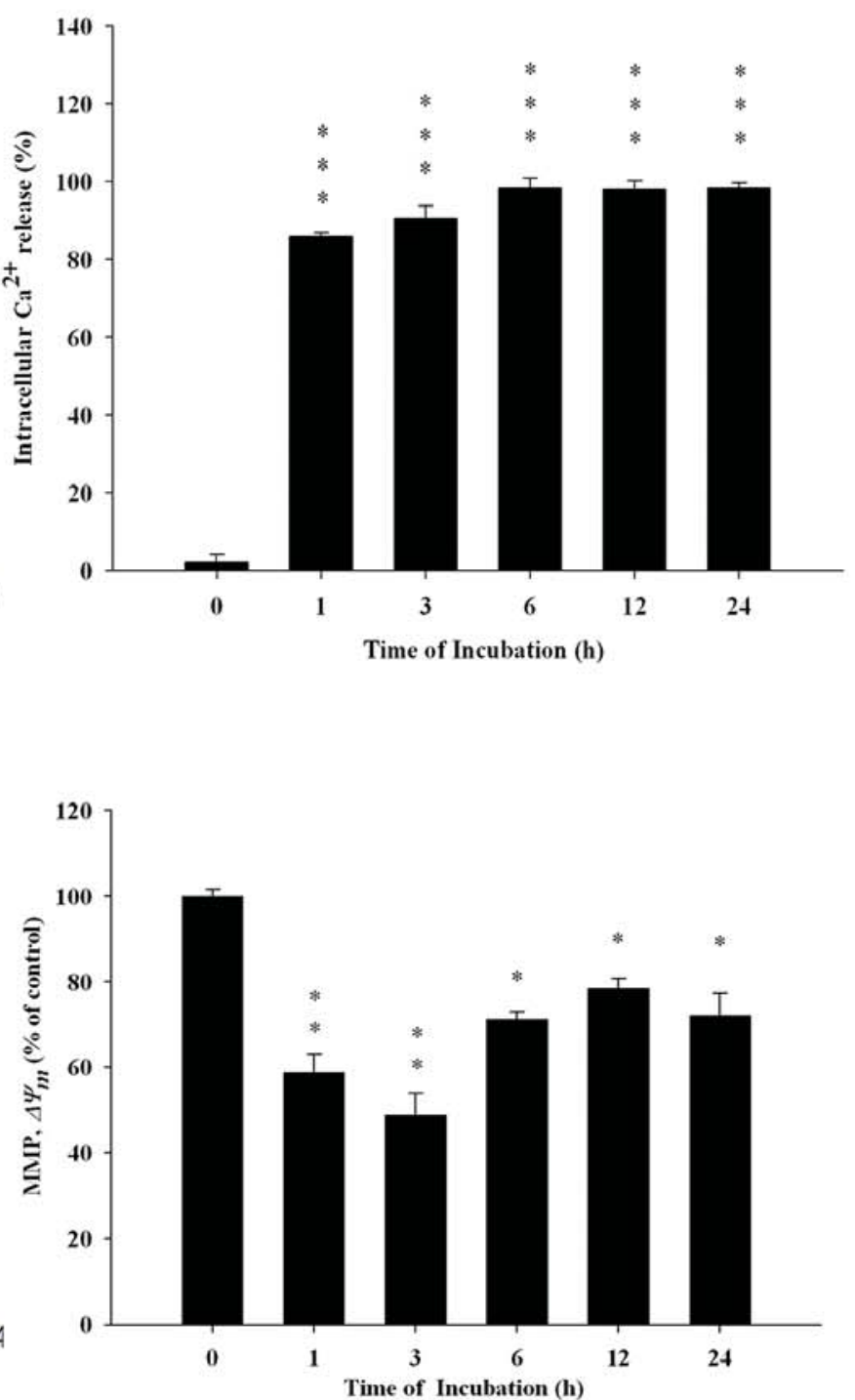

Figure 4. Curcumin induces production of reactive oxygen species (ROS) and $\mathrm{Ca}^{2+}$ and decreases the levels of mitochondria membrane potential ( $\left.\Delta \Psi_{\mathrm{m}}\right)$ in $\mathrm{N} 18$ cells. Cells were treated with $30 \mu \mathrm{M}$ curcumin for various time periods before cells were collected, stained by 2,7-dichlorodihydrofluorescein diacetate for ROS levels determined, stained by Indo 1/AM for $\mathrm{Ca}^{2+}$ levels determined and stained with DiOC ${ }_{6}$ for $\Delta \Psi_{\mathrm{m}}$ levels determined as described in Materials and methods. Data represent mean $\pm \mathrm{SD}$ of three experiments; ${ }^{*} \mathrm{P}<0.05,{ }^{* *} \mathrm{P}<0.01,{ }^{* * *} \mathrm{P}<0.001$. 
(A)

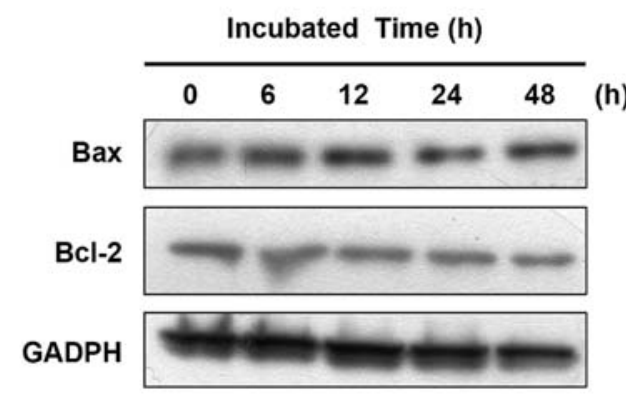

(C)

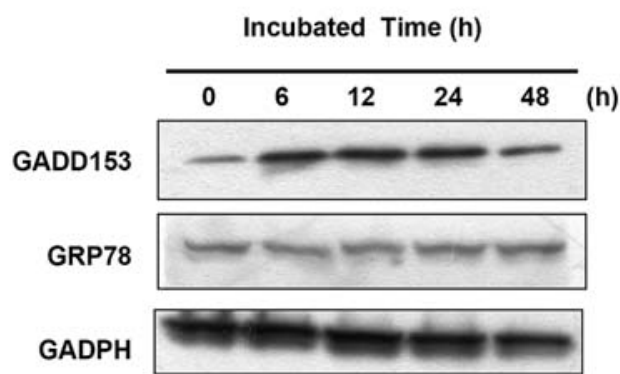

(E)

\begin{tabular}{cccccc}
\multicolumn{5}{c}{ Incubated Time (h) } \\
$\begin{array}{llllll}0 & 6 & 12 & 24 & 48 & \text { (h) }\end{array}$
\end{tabular}

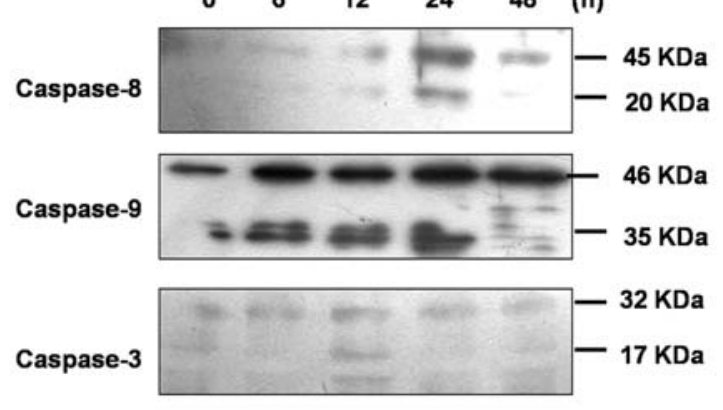

$\beta$-actin

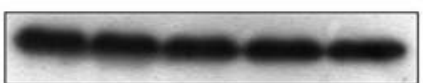

(D)
(B)
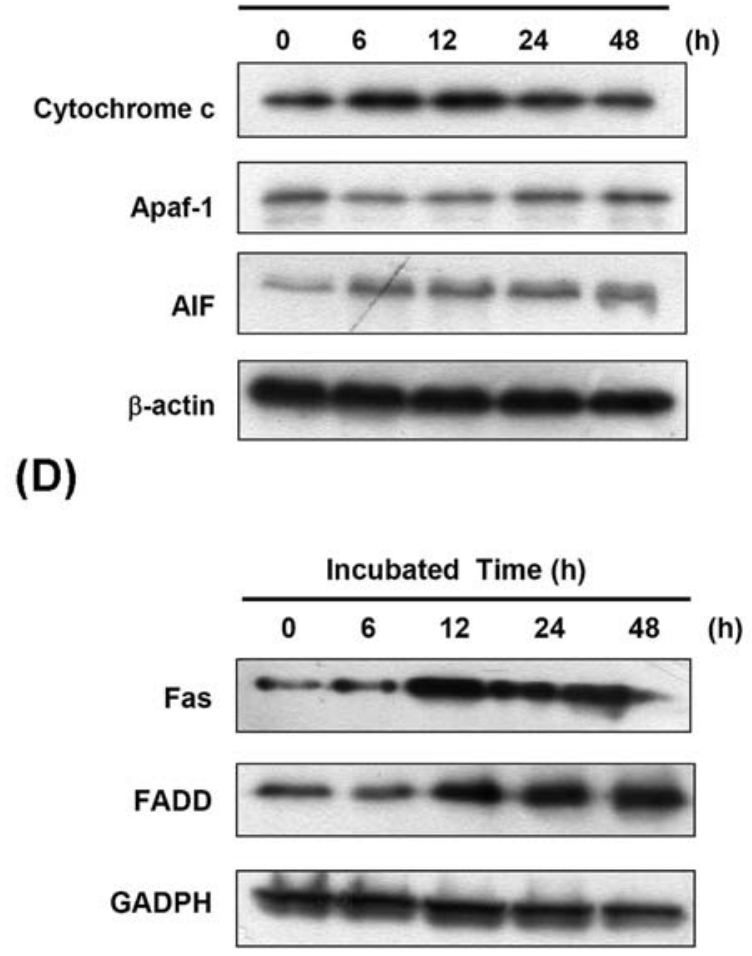

Figure 5. Curcumin affects the levels of associated proteins in apoptosis of $\mathrm{N} 18$ cell. Cells were treated with curcumin at $30 \mu \mathrm{M}$ for various time periods before cells were harvest for total proteins which were prepared and determined, as described in Materials and methods. The associated protein expressions (A: Bax and Bcl-2; B: cytochrome c, Apaf-1 and AIF; C: GADD153 and GRP78; D: Fas and FADD and E: caspase-8, -9 and -3 ) were estimated by Western blotting, as described in Materials and methods.

ganglion N18 cells. Flow cytometric analysis showed that N18 cells treated with different concentrations of curcumin for up to $48 \mathrm{~h}$ predominantly accumulated in the $\mathrm{G} 2 / \mathrm{M}$ phase of the cell cycle in a dose- and time-dependent manner, and with subsequent accumulation in the sub-G1 phase of cell cycle (Fig. 2A and B), suggesting the sequential events of cell cycle arrest followed by apoptosis. Apoptosis induced by curcumin was also confirmed by the observed changes in nuclear morphology by DAPI staining method (Fig. 3).

Apoptosis is a genetically regulated biological process with two major pathways: the extrinsic pathway involved in death-receptor and the intrinsic pathway involved in mitochondria apoptosome-mediated apoptosis (2). Bcl-2 family proteins such as Bax and Bcl-2 have a central role in controlling the mitochondrial pathway. The pro-apoptotic proteins and anti-apoptotic proteins of the Bcl-2 family may turn on and off apoptosis because of the formation of 


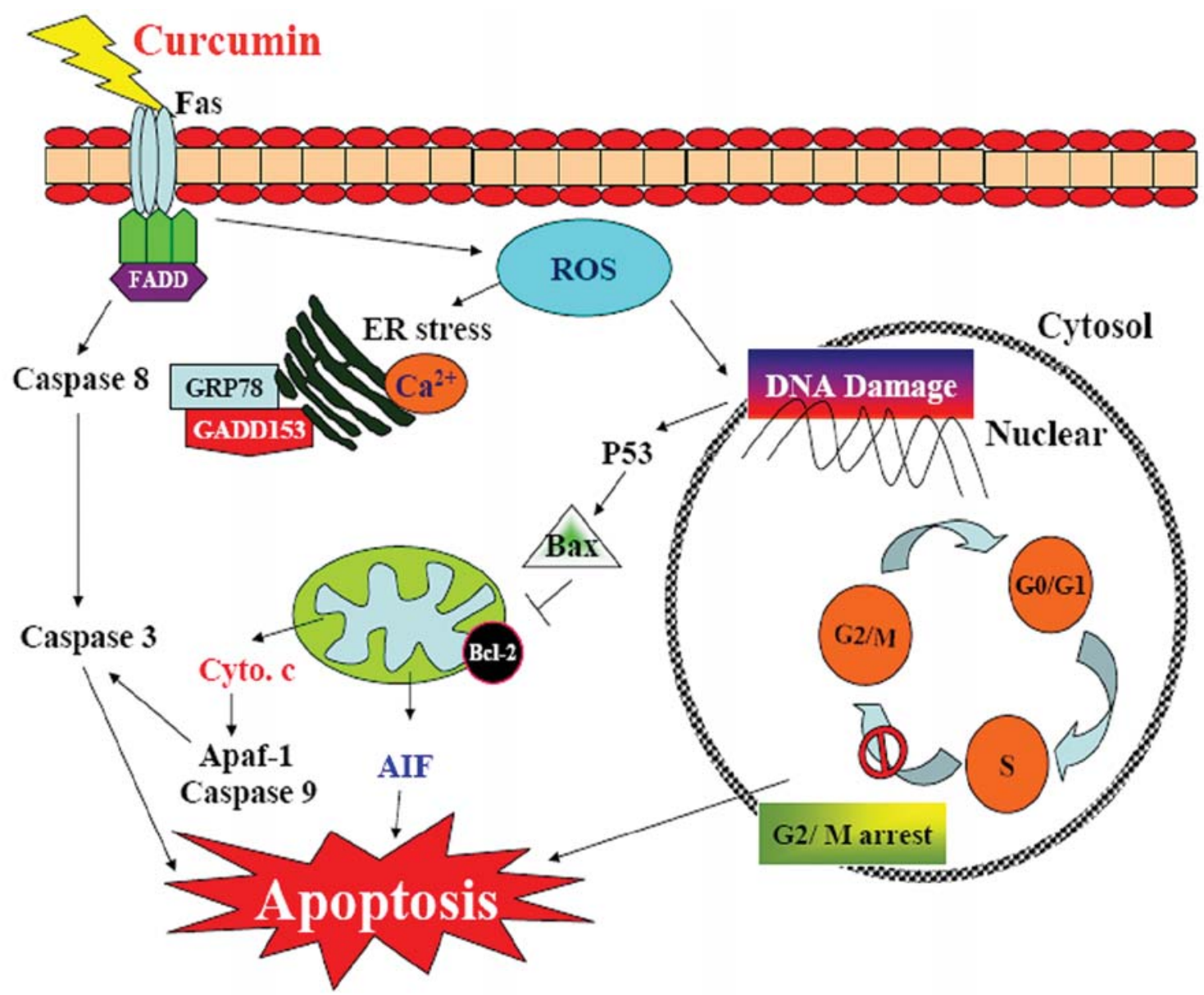

Figure 6. The proposed model of curcumin-mediated cell cycle arrest and apoptosis in mouse-rat hybrid retina ganglion N18 cells. Curcumin promoted the production of ROS and $\mathrm{Ca}^{2+}$ and reduced $\Delta \Psi_{\mathrm{m}}$ levels leading to cytochrome c and AIF release, and promoted caspase-8, -9 and -3 activation causing apoptosis in the N18 cells.

heterodimers among these proteins (29-31). The balance between the expression levels of the protein units (e.g. Bcl-2 and Bax) is critical for cell survival or death. In N18 cells treated with curcumin, the level of Bax was increased and Bcl-2 was decreased leading to decrease of the $\Delta \Psi_{\mathrm{m}}$ (Fig. 4C) suggesting that curcumin induced apoptosis through mitochondria-dependent pathway. In addition, human colon cancer cells lacking Bax also resist curcumin-induced apoptosis (32).

Many chemotherapeutic and chemopreventive agents have been shown to cause apoptotic cell death through caspasedependent pathway (33). Caspase-3 is an executioner caspase, which upon activation can systematically dismantle cells through cleaving PARP then lead to DNA fragmentation. Increased active form of caspase- 3 was observed in curcumintreated N18 cells (Fig. 5E). Caspase-3 plays an effector caspase that can be activated by different stimuli such as a mitochondrial pathway involving caspase- 9 or a death receptor pathway involving caspase- $8(34,35)$. In the present study, curcumin treatment increased the active form of caspase- 8 and -9 (Fig. 5E). Fig. 5 also showed that curcumin promoted Fas and FADD, caspase- 8 , -9 and -3 expression, cytochrome c levels. Fas plays an initial role for extrinsic pathway of apoptosis and it acts as a death-receptor for triggering apoptosis (2). These results suggest involvement of both mitochondrial and death receptor pathways in curcumin- induced apoptosis. The other important finding is that curcumin promoted the levels of GADD153 and GRP78 which are the hallmark of ER stress $(36,37)$ before leading to $\mathrm{Ca}^{2+}$ release. Therefore, we may also suggest that curcumin induced apoptosis in N18 cells also through the ER stress signaling pathway.

In summary, this study shows that curcumin is a potent growth inhibitor of cultured N18 cells. We characterized the molecular mechanisms underlying curcumin-induced apoptosis in N18 cells. The growth inhibition is related to the G2/M phase cell cycle arrest and the induction of apoptosis is associated with up-regulation of Bax and down-regulation of Bcl-2 (Fig. 6). The results provide the molecular basis for curcumin to act as an anti-tumor agent in cancer therapy. These findings should be helpful for the clinical application of curcumin in the future.

\section{Acknowledgements}

This work was supported by Grants CMU97-087 from the China Medical University of Taiwan.

\section{References}

1. Degterev A, Boyce M and Yuan J: A decade of caspases. Oncogene 22: 8543-8567, 2003. 
2. Ziegler DS and Kung AL: Therapeutic targeting of apoptosis pathways in cancer. Curr Opin Oncol 20: 97-103, 2008.

3. Klein S, McCormick F and Levitzki A: Killing time for cancer cells. Nat Rev Cancer 5: 573-580, 2005.

4. O'Neill J, Manion M, Schwartz P, et al: Promises and challenges of targeting bcl-2 anti-apoptotic proteins for cancer therapy. Biochim Biophys Acta 1705: 43-51, 2004.

5. Debatin KM: Apoptosis pathways in cancer and cancer therapy. Cancer Immunol Immunother 53: 153-159, 2004.

6. Green DR: Apoptotic pathways: Ten minutes to dead. Cell 121: 671-674, 2005

7. Sharma OP: Antioxidant activity of curcumin and related compounds. Biochem Pharmacol 25: 1811-1812, 1976.

8. Hanif R, Qiao L, Shiff SJ, et al: Curcumin, a natural plant phenolic food additive, inhibits cell proliferation and induces cell cycle changes in colon adenocarcinoma cell lines by a prostaglandin-independent pathway. J Lab Clin Med 130: 576-584, 1997.

9. Rao CV, Rivenson A, Simi B, et al: Chemoprevention of colon carcinogenesis by dietary curcumin, a naturally occurring plant phenolic compound. Cancer Res 55: 259-266, 1995.

10. Nagabhushan M and Bhide SV: Curcumin as an inhibitor of cancer. J Am Coll Nutr 11: 192-198, 1992.

11. Lu YP, Chang RL, Lou YR, et al: Effect of curcumin on 12-otetradecanoylphorbol-13-acetate- and ultraviolet b light-induced expression of c-jun and c-fos in jb6 cells and in mouse epidermis. Carcinogenesis 15: 2363-2370, 1994.

12. Kakar SS and Roy D: Curcumin inhibits TPA induced expression of c-fos, c-jun and c-myc proto-oncogenes messenger rRNA in mouse skin. Cancer Lett 87: 85-89, 1994.

13. Huang TS, Lee SC and Lin JK: Suppression of c-jun/AP-1 activation by an inhibitor of tumor promotion in mouse fibroblast cells. Proc Natl Acad Sci USA 88: 5292-5296, 1991.

14. Lloyd DR, Phillips DH and Carmichael PL: Generation of putative intrastrand cross-links and strand breaks in DNA by transition metal ion-mediated oxygen radical attack. Chem Res Toxicol 10: 393-400, 1997.

15. Xu J, Bubley GJ, Detrick B, et al: Chromium(vi) treatment of normal human lung cells results in guanine-specific DNA polymerase arrest, DNA-DNA cross-links and S-phase blockade of cell cycle. Carcinogenesis 17: 1511-1517, 1996.

16. Jana NR, Dikshit P, Goswami A, et al: Inhibition of proteasomal function by curcumin induces apoptosis through mitochondrial pathway. J Biol Chem 279: 11680-11685, 2004.

17. Logan-Smith MJ, East JM and Lee AG: Evidence for a global inhibitor-induced conformation change on the $\mathrm{Ca}(2+)$-ATPase of sarcoplasmic reticulum from paired inhibitor studies. Biochemistry 41: 2869-2875, 2002.

18. Logan-Smith MJ, Lockyer PJ, East JM, et al: Curcumin, a molecule that inhibits the $\mathrm{Ca}^{2+}$-atpase of sarcoplasmic reticulum but increases the rate of accumulation of $\mathrm{Ca}^{2+}$. J Biol Chem 276: 46905-46911, 2001.

19. Pae HO, Jeong SO, Jeong GS, et al: Curcumin induces proapoptotic endoplasmic reticulum stress in human leukemia HL-60 cells. Biochem Biophys Res Comm 353: 1040-1045, 2007.

20. Bakhshi J, Weinstein L, Poksay KS, et al: Coupling endoplasmic reticulum stress to the cell death program in mouse melanoma cells: Effect of curcumin. Apoptosis 13: 904-914, 2008.
21. Lin HL, Yang JS, Yang JH, et al: The role of $\mathrm{Ca}^{2+}$ on the dadsinduced apoptosis in mouse-rat hybrid retina ganglion cells (N18). Neurochem Res 31: 383-393, 2006.

22. Lin YT, Yang JS, Lin HJ, et al: Baicalein induces apoptosis in SCC-4 human tongue cancer cells via a $\mathrm{Ca}^{2+}$-dependent mitochondrial pathway. In Vivo 21: 1053-1058, 2007.

23. Lu HF, Chen YS, Yang JS, et al: Gypenosides induced G0/G1 arrest via inhibition of cyclin e and induction of apoptosis via activation of caspases-3 and -9 in human lung cancer A-549 cells. In Vivo 22: 215-221, 2008.

24. Wolf BB and Green DR: Suicidal tendencies: Apoptotic cell death by caspase family proteinases. J Biol Chem 274: 20049-20052, 1999.

25. Kaufmann SH, Desnoyers S, Ottaviano Y, et al: Specific proteolytic cleavage of poly(ADP-ribose) polymerase: An early marker of chemotherapy-induced apoptosis. Cancer Res 53: 3976-3985, 1993.

26. Su CC, Yang JS, Lin SY, et al: Curcumin inhibits wehi-3 leukemia cells in BALB/c mice in vivo. In Vivo 22: 63-68, 2008.

27. Xu K and Thornalley PJ: Involvement of glutathione metabolism in the cytotoxicity of the phenethyl isothiocyanate and its cysteine conjugate to human leukaemia cells in vitro. Biochem Pharmacol 61: 165-177, 2001.

28. Ushida J, Sugie S, Kawabata K, et al: Chemopreventive effect of curcumin on $\mathrm{N}$-nitrosomethylbenzylamine-induced esophageal carcinogenesis in rats. Jpn J Cancer Res 91: 893-898, 2000.

29. Ihmels H, Faulhaber K, Vedaldi D, et al: Intercalation of organic dye molecules into double-stranded DNA. Part 2: The annelated quinolizinium ion as a structural motif in DNA intercalators. Photochem Photobiol 81: 1107-1115, 2005.

30. Li TK, Bathory E, LaVoie EJ, et al: Human topoisomerase I poisoning by protoberberines: Potential roles for both drugDNA and drug-enzyme interactions. Biochemistry 39: 7107-7116, 2000.

31. Krey AK and Hahn FE: Berberine: complex with DNA. Science 166: 755-757, 1969.

32. Rashmi R, Kumar S and Karunagaran D: Human colon cancer cells lacking Bax resist curcumin-induced apoptosis and bax requirement is dispensable with ectopic expression of Smac or downregulation of Bcl-xl. Carcinogenesis 26: 713-723, 2005.

33. Su SH, Su SJ, Lin SR, et al: Cardiotoxin-III selectively enhances activation-induced apoptosis of human $\mathrm{CD}^{+} \mathrm{T}$ lymphocytes. Toxicol Appl Pharmacol 193: 97-105, 2003.

34. Budihardjo I, Oliver H, Lutter M, et al: Biochemical pathways of caspase activation during apoptosis. Annu Rev Cell Dev Biol 15: 269-290, 1999

35. Ashkenazi A and Dixit VM: Death receptors: Signaling and modulation. Science 281: 1305-1308, 1998.

36. Wu Y, Zhang H, Dong Y, et al: Endoplasmic reticulum stress signal mediators are targets of selenium action. Cancer Res 65: 9073-9079, 2005

37. Gomez-Santos C, Barrachina M, Gimenez-Xavier P, et al: Induction of c/ebp beta and gadd153 expression by dopamine in human neuroblastoma cells. Relationship with alpha-synuclein increase and cell damage. Brain Res Bull 65: 87-95, 2005. 